Journal of Agricultural Sciences
(Tarim Bilimleri Dergisi)

\title{
Rainwater Harvesting with Polyethylene Film Covered Ridges for Pumpkin (Cucurbita pepo L.) Seed Production Under Semiarid Conditions
}

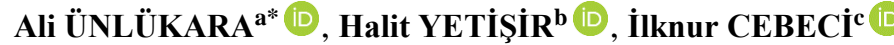

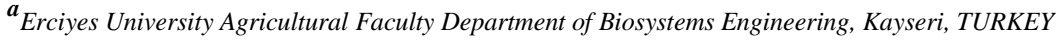

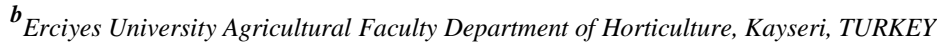

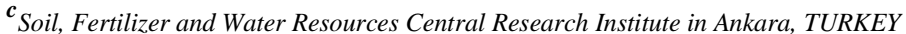

\section{ARTICLE INFO}

Research Article

Corresponding Author: Ali ÜNLÜKARA, E-mail: unlukara@erciyes.edu.tr

Received: 06 November 2019 / Revised: 20 February 2020 / Accepted: 18 March 2020 / Online: 04 September 2021

\section{ABSTRACT}

The aim of the study is to evaluate effectiveness of a rainwater harvesting technique with polyethylene film covered ridges (RHCR) on pumpkin seed production under rain-fed conditions in Kayseri/Turkey. For this purpose, a two-year experiment, of which were consisted three covered ridge widths $\left(R_{1}=0.5, R_{2}=0.7\right.$, and $\left.R_{3}=0.9 \mathrm{~m}\right)$ and a control treatment, was conducted. The experimental design was completely randomized plots in blocks with three replications. Significantly higher seed yields were obtained from $R_{2}$ and $R_{3}$ (202 and $208 \mathrm{~kg} \mathrm{ha}^{-1}$ ) in first year and from $\mathrm{R}_{2}$ (660 kg ha $\left.\mathrm{kg}^{-1}\right)$ in second year. Although excessive drought conditions were experienced during pumpkin growing period in those years, especially $\mathrm{R}_{2}$ treatment resulted significantly higher yield. Higher plant density in $R_{1}$ and lower density in $R_{3}$ negatively affected seed yield especially in water scarce second year. In second year, leaf area, mean fruit weight, fruit yield, seed yield and 1000-seed weight were found higher than ones in first year because of application of nitrogen a whole at sowing. We concluded that RHCR with optimum plant density and proper covered ridge wide, and application whole nitrogen at sowing under rain-fed conditions are effective ways to obtain higher pumpkin production in semiarid regions.

Keywords: Water harvesting, Micro catchment, Rainfed agriculture

(C) Ankara University, Faculty of Agriculture

\section{Introduction}

Generally, pumpkin seed consumed as snack in Turkey but has been also used as medicinal purposes in other countries (Yavuz et al. 2015; Babayee et al. 2012). Pumpkin seed production is one of the important livelihood ways of semiarid Middle Anatolian Regions of Turkey. Turkey pumpkin seed production was 41,326 tons from 64,964 ha in 2014 and great amounts of that production (71.8\%) were supplied in semiarid Middle Anatolian Region of Turkey, especially in Kayseri and Nevşehir provinces (TSI 2017). Since pumpkin seed can be stored for long durations such as 1 or 2 years, the farmers in the region can sell their production without experiencing considerable marketing problems (Yanmaz 2014).

Better rainwater management foresaw considerable scope for increased food production and poverty alleviation while minimizing additional water use and can help to upgrading rainfed agriculture (De Fraiture et al. 2010). The net return for a unit water used was described briefly as water productivity. Producing more food, income, better livelihoods and ecosystem services by using less water could be succeeded by improvement of water productivity. Practices that contribute the improvement in water productivity include water harvesting, supplemental irrigation, deficit irrigation, precision irrigation techniques and soilwater conservation practices (Molden et al. 2010).

Capturing precipitation from one part of the land and transfer it to another part is the basic principle of agricultural water harvesting that differs from traditional soil-water conservation practices, and water availability is increased, thereby $(\mathrm{Oweis}$ et al. 2012). A lot of techniques were experienced to harvest rainwater (Boers \& Ben-Asher 1982; Boers et al. 1986; Abu-Awwad 1999). Rainwater harvesting can be classified as flood-water, macro-catchment, micro-catchment, rooftop and courtyard water harvesting (Studer \& Liniger 2013). The main advantages of micro-catchment systems are simple, cheap, replicable, efficient and adaptable (Reij et al. 1988). Polyethylene (PE) covered ridge and furrow rainwater harvesting (RHCR) systems that were called as "ridge-furrow rain water harvesting" were classified as micro-catchment water harvesting techniques and considered as one of the most efficient harvesting methods. Ridges and furrows are built parallelly to counters on field surface for this technique and harvested rain waters from the covered ridge were concentrated to the furrows on where plants were grown. 
Different ridge and furrow ratios were used according to rain amount, rain intensity, crops and soil characteristics (Li et al. 2000; Tian et al. 2003; Wang et al. 2009).

The purpose of this study was to increase pumpkin seed yield and quality for rain-fed farming under semiarid conditions by harvesting rain water with polyethylene covered ridges and find out proper ridge width for Central Anatolian Region of Turkey.

\section{Material and Methods}

This research conducted two years by a collaboration of Erciyes University Agricultural Faculty and Ankara Soil, Fertilizer and Water Resources Central Research Institute to improve pumpkin seed yield and quality under semiarid rain-fed conditions in Develi/Kayseri/Turkey. Develi Research Station of the Agricultural Faculty is at $38^{\circ} 23^{\prime} \mathrm{N}$ latitude and $35^{\circ} 27^{\prime} \mathrm{E}$ longitude 1190 $\mathrm{m}$ above sea level. Long-term annual temperature of Kayseri province is $10.7^{\circ} \mathrm{C}$ and monthly mean temperatures varied from $1.7{ }^{\circ} \mathrm{C}$ for January and to $22.6^{\circ} \mathrm{C}$ for July. Total rainfall is $384.9 \mathrm{~mm}$ of which $28 \%$ fall in pumpkin growth period from $1 \mathrm{May}$ until 31 August (TSMS 2017). Reference evapotranspiration values (ETo), that represent atmospheric evaporative demand and estimated according to Allen et al. (1998), and some meteorological parameters for trial years were shown in Table 1. Total atmospheric evaporative demands (ETo) were 587 and $557 \mathrm{~mm}$ in 2013 and 2015, respectively. Therefore, ETo in 2013 growing season was $30 \mathrm{~mm}$ higher than one in 2015 .

Table 1- Reference evapotranspiration and some meteorological parameters for the trial years

\begin{tabular}{lcccccccc}
\hline & \multicolumn{9}{c}{2013} & \multicolumn{3}{c}{2015} \\
\cline { 2 - 9 } & May & June & July & August & May & June & July & August \\
\cline { 2 - 9 } $\mathrm{T}_{\min }\left({ }^{\circ} \mathrm{C}\right)$ & 11.1 & 13.1 & 14.7 & 14.7 & 9.6 & 12.3 & 14.5 & 16.7 \\
$\mathrm{~T}_{\max }\left({ }^{\circ} \mathrm{C}\right)$ & 24.2 & 27.8 & 29.7 & 30 & 22.2 & 25.1 & 30.3 & 31.5 \\
$\mathrm{RH}_{\min }(\%)$ & 26.2 & 19.4 & 18.7 & 17 & 29.2 & 32.5 & 20.7 & 21.9 \\
$\mathrm{RH}_{\max }(\%)$ & 70.4 & 65.9 & 60.1 & 58.1 & 76.8 & 85.7 & 66.8 & 70.4 \\
$\mathrm{n}($ hour $)$ & 287.6 & 363.2 & 395.9 & 383.3 & 285.6 & 276.9 & 391.8 & 370.9 \\
$\mathrm{U}_{2}(\mathrm{~m} / \mathrm{s})$ & 1.4 & 1.3 & 1.3 & 1.2 & 1.4 & 1.3 & 1.3 & 1.2 \\
$\mathrm{ETo}(\mathrm{mm})$ & 123 & 153 & 171 & 140 & 122 & 127 & 168 & 140 \\
\hline
\end{tabular}

$\mathrm{T}_{\min }$ and $\mathrm{T}_{\max }$; Monthly mean minimum and maximum temperature, $\mathrm{RH}_{\min }$ and $\mathrm{RH}_{\max }$; Monthly mean minimum and maximum relative humidity, $\mathrm{n}$; Monthly total sunshine duration, $\mathrm{U}_{2}$; Monthly mean wind speed at $2 \mathrm{~m}$ height, ETo; Reference evapotranspiration or atmospheric evaporative demand

Soil samples from the soil surface to $0.9 \mathrm{~m}$ deep for each $0.3 \mathrm{~m}$ soil layer were taken and analyzed in the collaborated Institute laboratories according to Tüzüner (1990). Soil texture was loamy sand and sandy loam with $175 \mathrm{~mm} \mathrm{~m}^{-1}$ available water holding capacity. Soil salinity was low $\left(\mathrm{ECe}<0.7 \mathrm{dS} \mathrm{m}^{-1}\right)$ and soil reaction was about 7.5 (Table 2).

Table 2- Some soil characteristics of Seyrani Agricultural Faculty Develi Research Station Area in Kayseri/Turkey

\begin{tabular}{lccccccccc}
\hline $\begin{array}{l}\text { Soil } \\
\text { Layers } \\
(\mathrm{cm})\end{array}$ & $\begin{array}{c}\text { Field } \\
\text { capacity } \\
(\%)\end{array}$ & $\begin{array}{c}\text { Wilting } \\
\text { point } \\
(\%)\end{array}$ & $\begin{array}{c}\text { Soil density } \\
\left(\mathrm{g} \mathrm{cm}^{-3}\right)\end{array}$ & $p H$ & $\begin{array}{c}E C_{e} \\
\left(d \mathrm{~S} \mathrm{~m}^{-1}\right)\end{array}$ & $\begin{array}{c}\text { Sand } \\
(\%)\end{array}$ & $\begin{array}{c}\text { Silt } \\
(\%)\end{array}$ & $\begin{array}{c}\text { Clay } \\
(\%)\end{array}$ & $\begin{array}{c}\text { Soil } \\
\text { tex. }\end{array}$ \\
\hline $0-30$ & 24.5 & 8.9 & 1.15 & 7.50 & 0.628 & 79.6 & 13.5 & 6.9 & LS \\
$30-60$ & 24.1 & 8.4 & 1.13 & 7.45 & 0.453 & 72.0 & 18.5 & 9.5 & SL \\
$60-90$ & 24.6 & 9.4 & 1.12 & 7.58 & 0.462 & 70.3 & 19.5 & 10.2 & SL \\
\hline
\end{tabular}

ECe; Electrical conductivity of soil saturation paste extract, LS; Loamy sand, SL; Silt loam

There were three rainwater harvesting treatments consisted of three different PE film covered ridge widths and a control treatment. PE film covered ridge widths were $0.5 \mathrm{~m}, 0.7 \mathrm{~m}$ and $0.9 \mathrm{~m}$ for $\mathrm{R}_{1}, \mathrm{R}_{2}$ and $\mathrm{R}_{3}$ treatments, respectively. Pumpkin plants were grown on $0.3 \mathrm{~m}$-width furrow areas also used for infiltration of harvested rainwater. Therefore, plant row spaces were 0.8 $\mathrm{m}, 1.0 \mathrm{~m}$ and $1.2 \mathrm{~m}$ for $\mathrm{R}_{1}, \mathrm{R}_{2}$ and $\mathrm{R}_{3}$ treatments, respectively (Figure 1). Rainwater harvesting with PE covered ridges treatments were compared to control treatment which represents conventional pumpkin cultivation in the region. Plant row space in control was $1.0 \mathrm{~m}$ and pumpkin plant spaces at rows for all treatments were $1.2 \mathrm{~m}$ in 2013 and $1.0 \mathrm{~m}$ in 2015 . Narrower plant distance in the second year was used to increase plant density and to obtain higher seed yield. The experimental design was completely randomized plots in blocks installed parallelly to counters. Three times replicated each treatment' plot had three rows and each row had 15 pumpkin plants. To avoid the side effect, the middle row of each replications was considered at harvest. Widely used Develi pumpkin population (Cucurbita pepo L.) called "pumpkin seed with frame" was utilized in the experiment. Polyethylene cover (PE+UV) was $0.1 \mathrm{~mm}$ thickness and resistant to ultraviolet radiation of sun (Figure 1). 

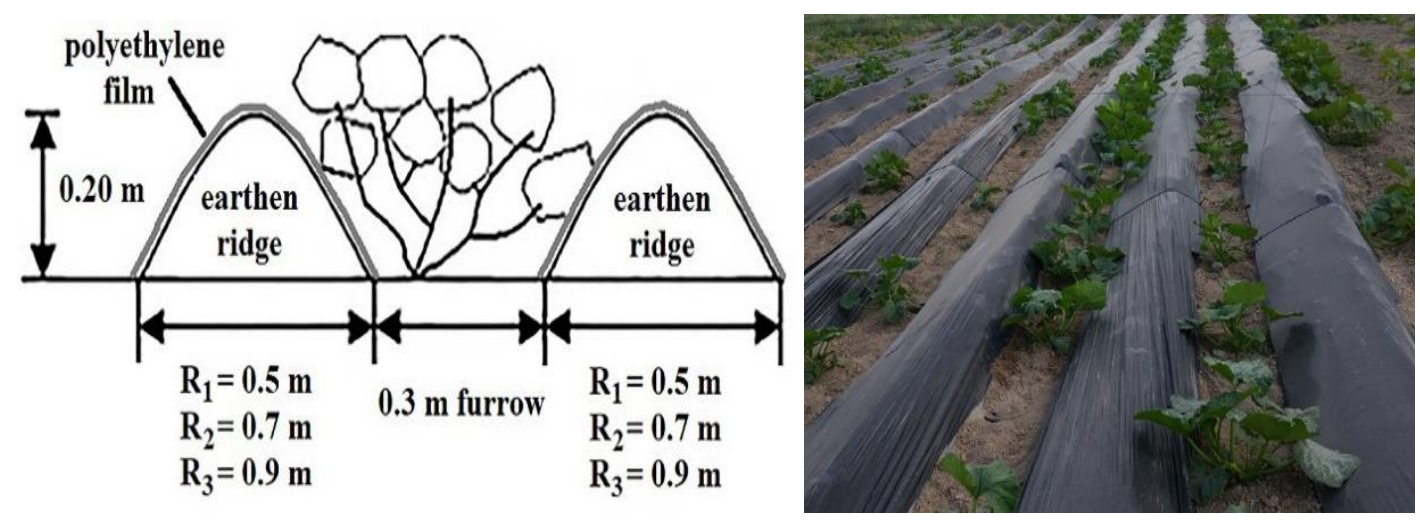

Figure 1- Rainwater harvesting with polyethylene film covered ridge (RHCR) techniques and experimental treatments

After soil tillage and preparation of ridge furrow system, $100 \mathrm{~kg} \mathrm{ha}^{-1}$ phosphorus $\left(\mathrm{P}_{2} \mathrm{O}_{5}\right), 100 \mathrm{~kg}$ ha ${ }^{-1}$ potassium $\left(\mathrm{K}_{2} \mathrm{O}\right)$ and $50 \%$ of $100 \mathrm{~kg} \mathrm{ha}^{-1}$ nitrogen $\left(\mathrm{NH}_{3}-\mathrm{NH}_{4}\right)$ applied at sowing (Vural et al. 2000) according to soil analysis and mixed in to the soil by hoeing manually in 2013. The rest of $50 \mathrm{~kg}$ nitrogen was applied at 3-4 true leaf stage. Because of light rains or possible nonrainy periods during the vegetative growth stage of pumpkin, all of the fertilizers applied at sowing time below seed bed in 2015 . Sowing and harvesting were performed on 26 April and 28 August in 2013 and on 1 May and 26 August in 2015, respectively. Pumpkin seeds were sowed about $3 \mathrm{~cm}$ below soil surface manually and 3 seeds were used for each point. After germination, one seedling at 1 true leaf stage was left by thinning.

Soil moisture of the treatments was monitored by 503 DR Hydroprobe neutron moisture meters. Soil moisture measurements were taken at $0.2,0.4,0.6$, and $0.8 \mathrm{~m}$ soil deeps in a $50 \mathrm{~mm}$-diameter aluminum access tubes by neutron probe. Soil moisture measurements were performed 4 times in 2013 and 9 times in 2015 (Figure 2). Neutron meter calibration and measurements were carried out according to the method offered by Evett (2007). Rain amounts were measured by pluviometers next to the experimental area. Plant water consumptions were determined by following Equation 1 based on soil water budget (James 1988; Wang et al. 2009):

$E T=I+P \pm \Delta W-d_{p}$

In where, ET pumpkin evapotranspiration $(\mathrm{mm}), \mathrm{I}$ irrigation water amount $(\mathrm{mm}), \mathrm{P}$ is rainfall amount (mm), $\Delta \mathrm{W}$ is stored soil water difference between the sowing and the harvest $(\mathrm{mm})$ and $d_{p}$ is deep percolation below root zone (mm). Irrigation amount (I) was considered zero because of rainfed conditions. Deep percolation was neglected due to light rains.
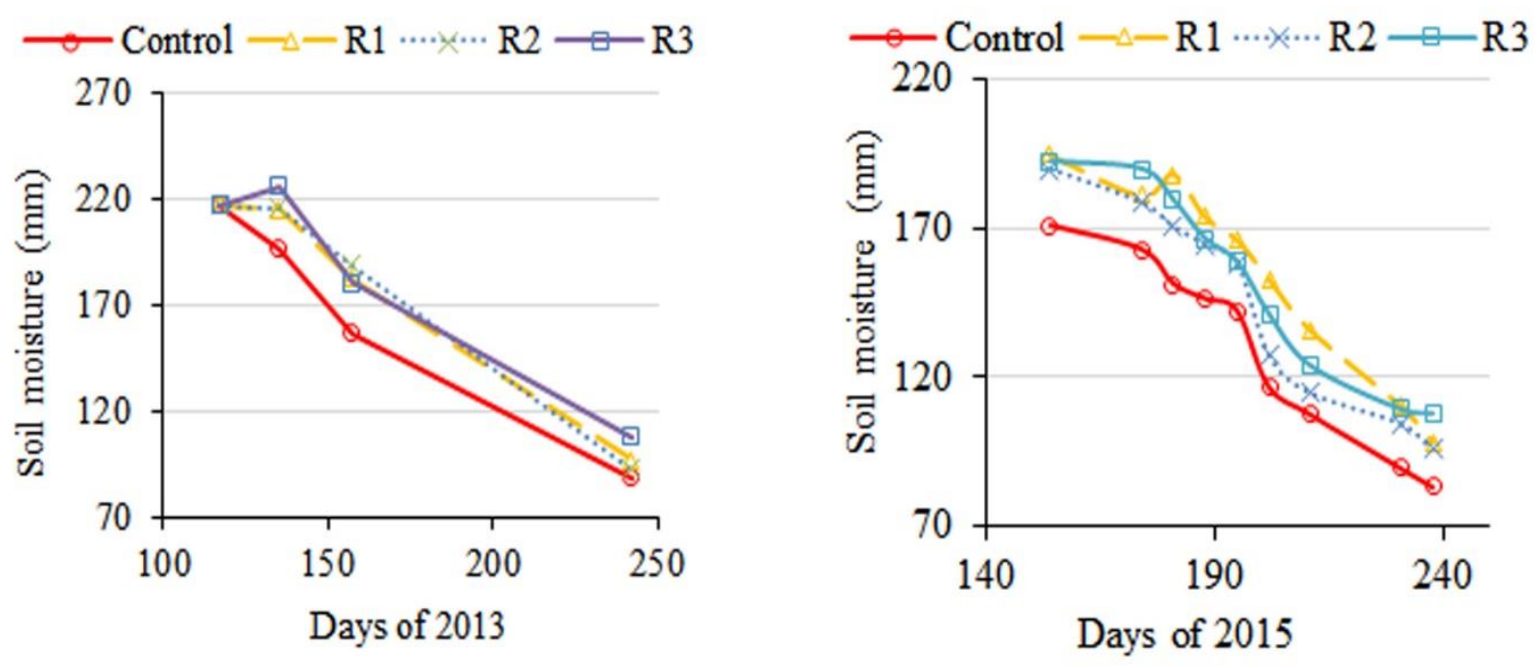

Figure 2- Soil moisture changes along growing season of pumpkin in 2013 and 2015

Mid-season leaf area of pumpkin was determined as a plant growth parameter by non-destructive method (Cemek et al. 2011). Relationships between leaf area and leaf dimensions (leaf width and length) were found out by regression and correlation analysis using 100 pumpkin leaves. Whole leaf dimensions (length and width) of five pumpkin plants for each treatment were measured at mid-season and then leaf areas were calculated based on these relationships. 
Fruit numbers and fruit weight of the middle rows were recorded at harvest. Pumpkin seeds were extracted from fruits manually and dried under sun light in plastic pans. Empty or partly empty pumpkin seeds were removed and then seed weight was determined. 1000 seeds were weighted as a seed quality parameter.

All data was subjected to variance analysis and means were compared at 0.05 probability level by Duncan Multiple Separation Test by SPSS 11.5 statistical software. Microsoft Excel 2016 software was used for regression and correlation analysis.

\section{Results}

\subsection{Rainfall and plant water consumption}

Precipitation date and rain amounts during pumpkin growth season were presented in Table 3 . Although the average rainfall of 55 years was $117 \mathrm{~mm}$ for the growing period (between $5^{\text {th }}$ and $8^{\text {th }}$ months), the recorded rainfalls for the growing period were only 24.2 and $13.8 \mathrm{~mm}$, in 2013 and 2015, respectively. Consequently, lower rainfall than regular precipitation during pumpkin growth season was occurred.

Table 3- Pumpkin evapotranspiration, soil moisture differences at the sowing and the harvest dates, rainy days and rain amount during pumpkin growth season in 2013 and 2015

\begin{tabular}{|c|c|c|c|c|c|c|c|c|c|c|}
\hline \multirow{7}{*}{2013} & Rain dates & 1 May & 2 May & 3 May & 12 May & 14 May & 18 May & 4 June & 10 June & Total \\
\hline & Rain amounts & 0.1 & 3.3 & 7.7 & 6.8 & 1.6 & 1.0 & 2.7 & 1.0 & 24.2 \\
\hline & Treatments & \multicolumn{2}{|c|}{$P(\mathrm{~mm})$} & \multicolumn{2}{|c|}{$\Delta W(m m)$} & & & & & $E T(\mathrm{~mm})$ \\
\hline & Control & \multicolumn{2}{|c|}{24.2} & \multicolumn{2}{|c|}{127.7} & & & & & 151.9 \\
\hline & $\mathrm{R}_{1}$ & \multicolumn{2}{|c|}{24.2} & \multicolumn{2}{|c|}{119.1} & & & & & 143.3 \\
\hline & $\mathrm{R}_{2}$ & \multicolumn{2}{|c|}{24.2} & \multicolumn{2}{|c|}{123.7} & & & & & 147.8 \\
\hline & $\mathrm{R}_{3}$ & \multicolumn{2}{|c|}{24.2} & \multicolumn{2}{|c|}{108.3} & & & & & 132.4 \\
\hline \multirow{7}{*}{2015} & Rain dates & 24 May & 31 May & 1 June & 3 June & 12 June & 16 June & & Total & \\
\hline & Rain amounts & 2.8 & 2.2 & 0.7 & 5.3 & 2.3 & 0.5 & & 13.8 & \\
\hline & Treatments & \multicolumn{2}{|c|}{$P(\mathrm{~mm})$} & \multicolumn{2}{|c|}{$\Delta W(\mathrm{~mm})$} & & & & & $E T(\mathrm{~mm})$ \\
\hline & Control & \multicolumn{2}{|c|}{13.8} & \multicolumn{2}{|c|}{87.2} & & & & & 101 \\
\hline & $\mathrm{R}_{1}$ & \multicolumn{2}{|c|}{13.8} & \multicolumn{2}{|c|}{96.2} & & & & & 110 \\
\hline & $\mathrm{R}_{2}$ & \multicolumn{2}{|c|}{13.8} & \multicolumn{2}{|c|}{93.8} & & & & & 107 \\
\hline & $\mathrm{R}_{3}$ & \multicolumn{2}{|c|}{13.8} & \multicolumn{2}{|c|}{84.2} & & & & & 98 \\
\hline
\end{tabular}

P; Rainfall (mm), $\Delta \mathrm{W}$; Soil water difference between the sowing and the harvest (mm), ET; Pumpkin evapotranspiration (mm), $\mathrm{R}_{1}, \mathrm{R}_{2}$ and $\mathrm{R}_{3}$; Rainwater harvesting treatments with $0.5,0.7$ and $0.9 \mathrm{~m}$ polyethylene covered ridge widths, respectively

Water consumption of control, $\mathrm{R}_{1}, \mathrm{R}_{2}$ and $\mathrm{R}_{3} \mathrm{RHCR}$ treatments were determined as $152,143,148$, and $132 \mathrm{~mm}$ in 2013 and $101,110,107$, and $98 \mathrm{~mm}$ in 2015, respectively. Not significant differences in plant water consumption were occurred among the treatments in both years. Although lower rainfall amounts were recorded during pumpkin growth season, pumpkin consumed higher than $98 \mathrm{~mm}$ water because of storing pre-season precipitations in the soil profile of its rooting depth. Averaged initial soil moistures for $0.9 \mathrm{~m}$ soil depth were $216 \mathrm{~mm}$ in 2013 and $196 \mathrm{~mm}$ in 2015, and averaged soil moisture at the harvest were around $97 \mathrm{~mm}$ in 2013 and $95 \mathrm{~mm}$ in 2015 (Figure 2). Therefore, great amounts of water for plant consumption were supplied from stored soil water in the rooting depth of pumpkin in the both of years (Table 3). Soil moistures along growing season in control treatment were lower than ones in RHCR treatments in 2013 and also lower in 2015 until 190 ${ }^{\text {th }}$ day of that year (Figure 2).

\subsection{Leaf area}

Leaf area, some yield components and 1000-seed weight presented in Table 4 and variance analyze results were shown in Table 5. Leaf area was considered as a growth parameter and determined at the full growth stage of pumpkin in a non-destructive manner. Stronger relationships $\left(\mathrm{R}^{2}=0.97\right)$ between leaf width-leaf area $\left(\mathrm{LA}=0.6397 \mathrm{~W}^{2}-1.6551 \mathrm{~W}+19.467\right)$ and leaf length-leaf area $\left(\mathrm{LA}=0.3709 \mathrm{~L}^{2}+10.859 \mathrm{~L}-54.463\right)$ were determined. Leaf area changed significantly for both years (Table 4). Leaf area varied from 0.151 to $0.256 \mathrm{~m}^{2}$ in 2013 and from 0.333 to $0.464 \mathrm{~m}^{2}$ in 2015 . Maximum leaf area $\left(0.256 \mathrm{~m}^{2}\right)$ was observed for $\mathrm{R}_{2}$ treatment and minimum leaf area $\left(0.151 \mathrm{~m}^{2}\right)$ for the control in $2013 . \mathrm{R}_{3}$ produced maximum leaf area $\left(0.464 \mathrm{~m}^{2}\right)$ and other treatments produced minimum leaf area $\left(0.333\right.$ to $\left.0.355 \mathrm{~m}^{2}\right)$ in 2015 . 
Table 4- Some growth and yield parameters of pumpkin plants grown under rainwater harvesting with polyethylene film covered ridge treatment and conventional cultivation in 2013 and 2015

\begin{tabular}{|c|c|c|c|c|c|c|c|}
\hline Year & & $\begin{array}{l}\text { Leaf area } \\
\left(m^{2}\right)\end{array}$ & $\begin{array}{c}\text { Mean } \\
\text { fruit wgt. } \\
(\mathrm{kg})\end{array}$ & $\begin{array}{l}\text { Fruit yield } \\
\left(\text { tha }^{-1}\right)\end{array}$ & $\begin{array}{c}\text { Fruit } \\
\text { seed } \\
\text { yield }(g)\end{array}$ & $\begin{array}{c}\text { Seed } \\
\text { yield } \\
\left(k g h a^{-1}\right)\end{array}$ & $\begin{array}{c}\text { 1000-seed } \\
\text { wgt. } \\
(\mathrm{g})\end{array}$ \\
\hline \multirow{4}{*}{2013} & Control & $0.151 \mathrm{c}$ & $0.67 \mathrm{~b}$ & $3.85 \mathrm{~b}$ & $9.7 \mathrm{c}$ & $55 \mathrm{~b}$ & $156 \mathrm{~b}$ \\
\hline & $\mathrm{R}_{1}$ & $0.189 \mathrm{bc}$ & $0.73 \mathrm{~b}$ & $4.20 \mathrm{~b}$ & $17.0 \mathrm{bc}$ & $112 \mathrm{ab}$ & $179 a b$ \\
\hline & $\mathrm{R}_{2}$ & $0.256 \mathrm{a}$ & $1.31 \mathrm{a}$ & $9.85 \mathrm{a}$ & $27.4 \mathrm{ab}$ & $202 \mathrm{a}$ & $199 \mathrm{ab}$ \\
\hline & $\mathrm{R}_{3}$ & $0.235 \mathrm{ab}$ & $1.14 \mathrm{ab}$ & $7.89 \mathrm{ab}$ & $30.0 \mathrm{a}$ & $208 \mathrm{a}$ & $210 \mathrm{a}$ \\
\hline \multirow{4}{*}{2015} & Control & $0.333 b$ & $1.87 \mathrm{c}$ & $20.50 \mathrm{~b}$ & $46.2 \mathrm{~b}$ & $512 \mathrm{ab}$ & $204 \mathrm{bc}$ \\
\hline & $\mathrm{R}_{1}$ & $0.355 \mathrm{~b}$ & $1.57 \mathrm{c}$ & $20.43 b$ & $30.3 \mathrm{c}$ & $397 \mathrm{~b}$ & $190 \mathrm{c}$ \\
\hline & $\mathrm{R}_{2}$ & $0.338 \mathrm{~b}$ & $2.60 \mathrm{~b}$ & $29.28 \mathrm{a}$ & $60.7 \mathrm{a}$ & $660 a$ & $234 \mathrm{ab}$ \\
\hline & $\mathrm{R}_{3}$ & $0.464 \mathrm{a}$ & $3.33 \mathrm{a}$ & $28.73 \mathrm{a}$ & $54.9 \mathrm{ab}$ & $478 \mathrm{~b}$ & $264 \mathrm{a}$ \\
\hline 2013 & & $0.208 \mathrm{~b}$ & $0.96 \mathrm{~b}$ & $6.45 b$ & $21.0 \mathrm{~b}$ & $144 \mathrm{~b}$ & $186 \mathrm{~b}$ \\
\hline 2015 & & $0.372 \mathrm{a}$ & $2.34 \mathrm{a}$ & $24.48 \mathrm{a}$ & $48.0 \mathrm{a}$ & $512 \mathrm{a}$ & $223 \mathrm{a}$ \\
\hline
\end{tabular}

Table 5- Variance analyze results

\begin{tabular}{lcccccc}
\hline & \multicolumn{3}{c}{2013} & \multicolumn{3}{c}{2015} \\
\cline { 2 - 7 } & Std. error & $F$ & Sig. & Std. error & S & Sig. \\
\cline { 2 - 7 } Leaf area & 0.0098 & 5.754 & 0.021 & 0.0148 & 4.306 & 0.044 \\
Mean fruit wgt. & 0.0726 & 4.567 & 0.038 & 0.108 & 13.403 & 0.002 \\
Fruit yield & 0.616 & 5.585 & 0.023 & 1.186 & 3.818 & 0.05 \\
Fruit seed yield & 1.894 & 6.184 & 0.018 & 1.978 & 11.232 & 0.003 \\
Seed yield & 21.284 & 3.038 & 0.05 & 20.869 & 6.924 & 0.013 \\
1000-seed wgt. & 5.205 & 5.302 & 0.026 & 5.297 & 9.601 & 0.005 \\
\hline
\end{tabular}

\subsection{Pumpkin fruit yield}

Maximum fruit yield obtained from $\mathrm{R}_{2}\left(9.85 \mathrm{tha}^{-1}\right)$ and $\mathrm{R}_{3}\left(7.89 \mathrm{t} \mathrm{ha}^{-1}\right)$ while minimum ones from the control (3.85 $\left.\mathrm{t} \mathrm{ha} \mathrm{a}^{-1}\right)$ and $\mathrm{R}_{1}\left(4.20 \mathrm{t} \mathrm{ha}^{-1}\right)$ in 2013 (Table 4). Minimum fruit yields in the second year were harvested again from the control as $20.5 \mathrm{t}$ ha ${ }^{-1}$ and $\mathrm{R}_{1}$ as $20.43 \mathrm{t} \mathrm{ha}^{-1} . \mathrm{R}_{2}$ and $\mathrm{R}_{3}$ treatments produced maximum fruit yields as 29.28 and 28.73 t/ha, respectively (Table 4 ). Similar results were obtained for mean fruit weights (Table 4). Mean fruit weight was changed significantly. In the first year, the control and $R_{1}$ treatments produced the lower fruit weights as 0.67 and $0.73 \mathrm{~kg}_{\text {fruit }}^{-1}$, respectively while the heavier ones were produced by $R_{2}$ and $R_{3}$ as 1.31 and $1.14 \mathrm{~kg}_{\text {fruit }}{ }^{-1}$, respectively. In second year, mean fruit weights were obtained as $2.34 \mathrm{~kg}$ fruit ${ }^{1}$ and the heaviest fruits were harvested from $\mathrm{R}_{3}(3.33 \mathrm{~kg}) . \mathrm{R}_{1}$ and the control treatments produced the smallest fruits (Table 4).

\subsection{Seed yield}

Significant differences in seed yield among treatments both in 2013 and 2015 were found. Maximum seed yields as 202 and 208 $\mathrm{kg} \mathrm{ha}^{-1}$ were obtained from $\mathrm{R}_{2}$ and $\mathrm{R}_{3}$, respectively, while minimum seed yield was $55 \mathrm{~kg} \mathrm{ha}^{-1}$ in the control treatment in 2013 (Table 4). In 2015, maximum seed yield as $660 \mathrm{~kg} \mathrm{ha}^{-1}$ was harvested from $\mathrm{R}_{2}$ and minimum seed yield as $397 \mathrm{~kg}$ ha-1 was harvested from $R_{1}$. Higher seed yields were obtained from $R_{2}$ treatment for both years.

\subsection{0 seed weight}

In both years, 1000-seed weight was affected significantly by the treatments. In 2013 , the highest 1000 -seed weights as $210 \mathrm{~g}$ was recorded in $\mathrm{R}_{3}$ water harvesting treatment and the least one as $156 \mathrm{~g}$ was recorded in the control (Table 4). In 2015, the highest 1000-seed weight $264 \mathrm{~g}$ from $\mathrm{R}_{3}$ and the least 1000 -seed weight $190 \mathrm{~g}$ from $\mathrm{R}_{1}$ were obtained.

\section{Discussion}

Pumpkin water consumption in this region was estimated $430 \mathrm{~mm}$ under full irrigation conditions according to FAO-56 PenmanMonteith method (Ünlükara 2014). Pumpkin mean water consumption under full irrigation and rainfed conditions were determined as 474 and $293 \mathrm{~mm}$ in Kayseri (Kirnak et al. 2019), as 645 and $201 \mathrm{~mm}$ in Konya (Yavuz et al. 2015) and as 539 and $336 \mathrm{~mm}$ for squash in Van (Ertek et al. 2004). Water stress free squash (C. pepo L.) consumed $304 \mathrm{~mm}$ and $344 \mathrm{~mm}$ water under trickle and furrow irrigation for spring period in Egypt (Amer 2011). Pumpkin water consumptions in the current experiment were found less than the ones above mentioned because lower rainfalls were recorded in pumpkin growing season for both experimental years. However, Zotarelli et al. (2008) reported 108 to $171 \mathrm{~mm}$ water consumption for zucchini cultivated with a plastic mulch bed system in Florida for two years under full irrigation. Plastic mulching considerably reduced water consumption of pumpkin in that experiment. 
In 2013, leaf area, mean fruit weight, fruit yield, seed yield per fruit, seed yield and 1000-seed yield were higher in RHCR treatments than ones in the control treatment. In 2015, maximum leaf area, fruit weight and 1000-seed weight were found in $R_{3}$, maximum fruit yield in both $R_{2}$ and $R_{3}$, maximum seed yield per fruit and seed yield in $R_{2}$. The purpose of pumpkin farming in semiarid middle Anatolian region of Turkey is to produce pumpkin seed for confectionary consumption. Especially, RHCR treatment with $0.70 \mathrm{~m}$ covered ridge $\left(\mathrm{R}_{2}\right)$ improved pumpkin seed yield and nearly all growth and yield parameters for both experimental years. In severely drought 2015 , higher plant density in $\mathrm{R}_{1}$ reduced both seed yield and quality because of competition for water. $\mathrm{R}_{3}$ treatment improved 1000-seed weight but reduced seed yield because of its lower plant density in unit area.

Fruit yields in $\mathrm{R}_{1}, \mathrm{R}_{2}$ and $\mathrm{R}_{3}$ were found $9 \%, 156 \%$ and $105 \%$ higher than the control in 2013 and $0 \%$, 43\% and $40 \%$ higher in 2015. RHCR treatments improved fruit yield considerably. Mean fruit yields of RHCR treatment for two years were 6.45 and $29.28 \mathrm{t} \mathrm{ha}^{-1}$. In researches in semiarid conditions in Turkey, 14.8 and $7.3 \mathrm{tha}^{-1}$ pumpkin fruit yields for two years were obtained (Yavuz et al. 2015). Comparing to results reported by Yavuz et al. (2015), we obtained higher fruit yields in second year. Tian et al. (2003) also reported that larger potato tubers obtained from RHCR and smaller tubers from control treatment.

$\mathrm{R}_{1}, \mathrm{R}_{2}$ and $\mathrm{R}_{3}$ treatments improved seed yield 104\%, 267\%, and 278\% compared with the control in 2013. Mean seed yield increase for $\mathrm{R}_{2}$ was $29 \%$ according the control in 2015. Similar to our findings, Tian et al. (2003) found $219 \%$ yield increase in potato grown in RHCR system. Wang et al. (2009) also determined sweet sorghum biomass yield increases from the RHCR technique with covered both ridge and furrow and the RHCR technique with covered ridge compared with conventional cultivation and non-covered ridge and furrow technique.

Kirnak et al. (2019) obtained 470 and $427 \mathrm{~kg} \mathrm{ha}^{-1}$ pumpkin seed yield against $256 \mathrm{~mm}$ and $227 \mathrm{~mm}$ water consumption and, Yavuz et al. (2015) reported 545 and $247 \mathrm{~kg} \mathrm{ha}^{-1}$ seed yield against $194.2 \mathrm{~mm}$ and $208.2 \mathrm{~mm}$ water consumption under rainfed conditions. We obtained $606 \mathrm{~kg} \mathrm{ha}^{-1}$ seed yield against $110 \mathrm{~mm}$ water consumption for $\mathrm{R}_{2}$ in 2015 . Covered ridges concentrate harvested rainwater to furrow areas and allow harvested water to percolate and to store in the soil profile deeply. Undesirable evaporation losses from relatively narrow furrow surface beneath crop canopy decreased greatly in RHCR. Furthermore, covered ridges keep soil moisture before and during the growing season and promote plant transpiration. The main reason for yield increase of RHCR system resulted from preventing evaporation and improving available water for plant transpiration.

All parameters considered in the current experiment were found higher in second year. The main reason was changing nitrogen application. In 2013, nitrogen divided into two parts and the first part was applied at sowing and the second part was applied at 3 or 4 leaf stage. But in 2015, whole fertilizers were applied during the sowing. We observed that nitrogen application by dividing several parts in rain-fed conditions was not efficient due to low rainfall characteristic of the region. Drier soil surface during the application of second nitrogen part resulted inefficient use of nitrogen. Similar result also reported by Dumanlar (2018) for pumpkin even in full irrigation. Maximum pumpkin growth and yield characteristics were obtained by application whole nitrogen need at sowing. Although plant densities for control, $\mathrm{R}_{1}, \mathrm{R}_{2}$ and $\mathrm{R}_{3}$ treatments increased $20 \%$ in the second year, seed yield increased $831 \%, 254 \%, 227 \%$ and $130 \%$, respectively. We concluded that great amount of seed yield increase resulted from application whole fertilizers at sowing.

\section{Conclusions}

Effects of rainwater harvesting technique with PE film covered ridges were investigated for pumpkin growth and yield under semiarid rainfed conditions of Develi/Kayseri in Turkey for two years. RHCR treatments had plastic covered ridges with 0.5 , 0.7 and $0.9 \mathrm{~m}$ widths and all treatments had constant $0.3 \mathrm{~m}$ furrow width between these covered ridges. RHCR treatments and conventional pumpkin farming treatment (the control) in the region were compared. We concluded according to our findings that:

- RHCR technique improved pumpkin growth, fruit yield, seed yield and 1000-seed weight considerably by relatively preventing evaporation from soil surface and by increasing transpiration. Because of these positive effects of RHCR, we concluded that RHCR is one of ways to increase pumpkin production and quality in rainfed farming under semi-arid regions of Turkey.

- Considering seed yield of two trial years, polyethylene film covered ridges with $0.7 \mathrm{~m}$ width came in prominence with higher pumpkin yield and quality despite scarce rainfall in pumpkin growing season. It is suggested to use $0.7 \mathrm{~m}$ covered ridge and 0.3 $\mathrm{m}$ furrow widths to decrease plant competition for soil water and prevent plant failure and to obtain higher seed yield under RHCR technique.

- Fertilizer need of pumpkin should be applied at sowing stage as a whole to improve efficient utilization under semi-arid rainfed conditions. Under semi-arid rainfed conditions, applying nitrogen requirement of pumpkin by dividing in to several parts caused poor growth and yield because of possibly insufficient and lower rainfalls during growth stage of pumpkin. 


\section{Acknowledgements}

This work was supported by General Directorate of Agricultural Research and Policies of Republic of Turkey Ministry of Food Agriculture and Livestock [TAGEM/TSKAD/12/A13/P02/1]. Thanks to İnci Petekkaya, Füsun Sarısamur and Mahmut Hilmi Seçmen because of their contributions.

\section{References}

Abu-Awwad A M (1999). Effects of sand column, furrow and supplemental irrigation on agricultural production in an arid environment. Irrigation Science 18: 191-197 https://doi.org/10.1007/s002710050062

Allen R G, Pereira L S, Raes D, Smith M (1998). Crop evapotranspiration. Guidelines for computing crop water requirements. FAO Irrigation and Drainage Paper No.56, Rome

Amer K H (2011). Effect of irrigation method and quality on squash yield and quality. Agricultural Water Management 98:1197-1206 https://doi.org/10.1016/j.agwat.2011.03.003

Babayee S A, Daneshian J \& Valadabani S A R (2012). Effect of plant density and irrigation interval on some grain characteristics of pumpkin (Cucurbita pepo L.). International Journal of Agriculture and Crop Sciences 4-8: 439-442

Boers T M \& Ben-Asher J (1982). A review of rainwater harvesting. Agricultural Water Management 5: 145-158 https://doi.org/10.1016/03783774(82)90003-8

Boers TM, Zondervan J \& Ben-Asher J (1986). Micro-catchment-water-harvesting (MCWH) for arid zone development. Agricultural Water Management 12:21-39 https://doi.org/10.1016/0378-3774(86)90003-x

Cemek B, Unlukara A \& Kurunc A (2011). Nondestructive leaf-area estimation and validation for green pepper (Capsicum annuum L.) grown under different stress conditions. Photosynthetica 49(1): 98-106 https://doi.org/10.1007/s11099-011-0010-6

De Fraiture C, Molden D \& Wichelns D (2010). Investing in water for food, ecosystems, and livelihoods: An overview of the comprehensive assessment of water management in agriculture. Agricultural Water Management 97: 495-501 https://doi.org/10.1016/j.agwat.2009.08.015

Dumanlar N (2018). Effects of different nitrogen rate application during sowing to pumpkin (Cucurbita pepo L.) growth, yield, evapotranspiration and water use efficiency. Msc Thesis (Published), Erciyes University, Turkey

Ertek A, Şensoy S, Küçükyumuk C \& Gedik İ (2004). Irrigation frequency and amount affect yield component of summer squash (Cucurbita pepo L.). Agricultural Water Management 67: 63-76 https://doi.org/10.1016/j.agwat.2003.12.004

Evett S (2007). Soil water and monitoring technology. In: RJ Laskano \& RE Sojka (Eds.), Irrigation of agricultural crops, American Society of Agronomy, Madison, pp. 25-84

James L G (1988). Principles of farm irrigation system design. Singapore: John Wiley and Sons, Singapore

Kirnak H, Irik H A \& Unlukara A (2019). Potential use of crop stress index (CWSI) in irrigation scheduling of drip-irrigated seed pumpkin plants with different irrigation levels. Scientia Horticulturae 256: 108608 https://doi.org/10.1016/j.scienta.2019.108608

Li X Y, Gong J-D, Gao Q Z \& Wei X-H (2000). In-situ rain water harvesting and gravel mulch combination for corn production in the dry semiarid region of China. Journal of Arid Environment 46: 371-382 https://doi.org/10.1006/jare.2000.0705

Molden D, Oweis T, Steduto P, Bindraban P, Hanjra MA \& Kijne J (2010). Improving agricultural water productivity: Between optimism and caution. Agricultural Water Management 97: 528-535 https://doi.org/10.1016/j.agwat.2009.03.023

Oweis T, Prinz D \& Hachum A Y (2012). Water harvesting for agriculture in the dry areas. CRC Press, Taylor and Francis Group, London

Reij C, Mulder P \& Begeman L (1988). Water harvesting for plant production. World Bank Technical paper 91, Washington

Studer R M \& Liniger H (2013). Water harvesting. Guidelines to good practice. International Fund for Agricultural Development, Rome

Tian Y, Su D, Li F \& Li X 2003. Effect of rainwater harvesting with ridge and furrow on yield of potato in semiarid areas. Field Crops Res. 84: 385-391 https://doi.org/10.1016/s0378-4290(03)00118-7

TSI 2017. Turkish Statistical Institute (2017). Main Statistics. Retrieved in April, 21, 2017 from http://www.tuik.gov.tr/PreTablo.do?alt_id=1001

TSMS 2017. Turkish State Meteorological Service, Weather Forecast. Retrieved in April, 21, 2017 from https://mgm.gov.tr/eng/forecastcities.aspx?m=KAYSERI

Tüzüner A (1990). Laboratory Handbook of Soil and Water Analyze. General Directorate of Village Works of Agriculture and Forest Ministry of Turkish Republic, Ankara (In English)

Ünlükara A 2014. Confectionary pumpkin water relationships and irrigating strategy. In: Workshop on Confectionary Pumpkin, 26-27 November, Kayseri, pp. 69-80 (In English)

Wang Y, Xie Z, Malhi S S, Vera C L, Zhang Y \& Wang J (2009). Effects of rainwater harvesting and mulching technologies on water use efficiency and crop yield in the semiarid Loess Plateau, China. Agricultural Water Management 96: 374-382 https://doi.org/10.1016/j.agwat.2008.09.012

Vural H, Eşiyok D \& Duman İ (2000). Kültür Sebzeleri. Ege Üniversitesi Basımevi, İzmir (In English)

Yanmaz R 2014. Confectionary pumpkin potential of Turkey. In: Workshop on Confectionary Pumpkin, 26-27 November, Kayseri, pp. 1-12 (In English)

Yavuz D, Seymen M, Yavuz N \& Türkmen Ö (2015). Effects of irrigation interval and quantity of confectionary pumpkin grown under field conditions. Agricultural Water Management 159: 290-298 https://doi.org/10.1016/j.agwat.2015.06.025

Zotarelli L, Dukes M D, Scholberg J M, Hanselman T, Le Femminella K \& Munoz-Carpena R (2008). Nitrogen and water use efficiency of zucchini squash for a plastic mulch bed system on a sandy soil. Scientia Horticulturae 116: 8-16 https://doi.org/10.1016/j.scienta.2007.10.029

C 2021 by the authors. Licensee Ankara University, Faculty of Agriculture, Ankara, Turkey. This article is an open access article distributed under the terms and conditions of the Creative Commons Attribution (CC BY) license (http://creativecommons.org/licenses/by/4.0/). 